\title{
GEOGRAPHIES OF THEATRE: \\ THE FINNISH NATIONAL THEATRE IN STOCKHOLM IN 1956
}

\section{HANNA KORSBERG}

\begin{abstract}
During the Cold War, the Finnish National Theatre actively sought possibilities for international visits and co-operation. It wanted to showcase its work abroad and especially connect itself with Western European theatres. In 1956, the Finnish National Theatre visited Stockholm. In terms of politics, it was interesting that the Finnish National Theatre chose to perform Aleksis Kivi's The Seven Brothers and especially interesting that it performed Anton Chekhov's The Three Sisters. It seems to be the case that there was a national border between the Finnish National Theatre and Anton Chekhov's play that was hard to cross. The director of the production, Eino Kalima, was described as an expert in interpreting Chekhov due to his background as a student of Stanislavski. This was a myth created by the director of the Finnish National Theatre. However, it increased international interest for the production of The Three Sisters with Kalima as its director. Furthermore, it supported the theatre's attempts at seeking mobility and engaging in international, cultural encounters.
\end{abstract}

Keywords: Cold War, cultural politics, geographies of theatre, international relations, theatre visits

After World War II, Finland returned slowly to the international community. It was in a very delicate geopolitical position between the Western and Eastern Blocs. As part of the re-establishing of Finlands international connections, the Finnish National Theatre actively sought for possibilities for international visits and co-operation. It wanted to showcase its work abroad, especially by connecting itself mainly to other national theatres. During the years Arvi Kivimaa was the director of the Finnish National Theatre in 1950-1974, the theatre looked mainly westward: it visited abroad fourteen times and many of the well-known European theatres performed in Helsinki at the Finnish National
Theatre. The main international interest was drawn to the productions of The Three Sisters and The Seagull with which the Finnish National Theatre visited European theatres five times in 1956-1963.

In this article, I discuss the guest performances the Finnish National Theatre performed at the Royal Dramatic Theatre in Stockholm, Sweden in May 1956. The performances were The Thre Sisters by Chekhov and The Seven Brothers, an adaptation of a novel by Aleksis Kivi. It was the first time the Finnish National Theatre travelled abroad performing an Anton Chekhov production directed by Eino Kalima. I analyse the visit by discussing geographies of theatre. As 
Joanne Tompkins has defined, theatre's geographies incorporate not only architectural but also narrative and more abstract interpretations of spatiality and theatre's connection to a historical, social, and cultural context. ${ }^{1}$ I propose that in addition to this, geographies of theatre also incorporate theatre's artistic and political contexts. For example, in my case study, it is not only a question of the nationality of the play which is produced in a particular place in a certain historical moment, but also the question of showcasing the artistic work of a theatre and the branding of an art institution abroad. It seems to be that producing Anton Chekhov's plays in post wartime Finland was not uncomplicated. It seems that there was a symbolic border between the theatre and the play that was hard to cross at the time. It was especially difficult for the Finnish National Theatre to showcase their work abroad with a Chekhov play.

In order to cross national borders and increase international interest towards the production of Chekhov, the Finnish National Theatre created the myth of Kalima being a student of Stanislavski at the time of the Stockholm visit. I will begin by looking at the preliminary decisionmaking-process at the Finnish National Theatre. What were the artistic, cultural and/or political reasons for choosing these two productions, how did the Finnish National Theatre negotiate the geographies of theatre, and, eventually, what was the reason for creating the myth? One of the visiting productions was an internationally known classic and the other one was an adaptation of a Finnish novel, The Seven Brothers by Aleksis Kivi, which the Swedish audience did not know in advance. I will then look at the reception of these two performances in Stockholm. How did the Swedish critics participate in the process of creating and sustaining the myth as authoritative experts? How did they describe the guest performances in terms of theatrical style and national questions?

\section{ARVI KIVIMAA AND THE PLANNING OF THE VISIT}

Right after the war, preparations for the Peace
Treaty between Finland and the Soviet Union inhibited any attempts for Finland to join the international community. For example, Finland had to refuse Marshall Aid, the European rebuilding programme initiated by the USA in 1947. After the Paris Peace Treaty in 1947, the Foreign Ministry of Finland approached the General Secretary of the UN who set in motion Finland's application for membership. However, due to the Cold War and the fear of endangering the existing balance of power in the UN, Finland could not join the organization before 1955. The year 1955 was a significant turning point in Finland's international position: the country could join both the Nordic Council and the UN. ${ }^{2}$ Johanna Rainio-Niemi has argued that during the Cold War, Finlands neutrality was a pragmatic choice determined by the vicinity of the Soviet Union. However, Finland tried to find as many options for western European integration as possible. ${ }^{3}$ I would argue that since Finland had to remain outside of many international alliances during the Cold War, especially of a political and economic character, culture and theatre in particular opened up new possibilities for international interaction and exchange. For example, Finland became an official member of the International Theatre Institute, ITI, already in $1950 .{ }^{4}$ In 1950 s internationalism the nation states were considered important. They were considered the agents connecting other nation states. Theatre productions, partly with the influence of the ITI, started to circulate across the globe. Theatre proved itself a point of contact for different nations: productions, artists, and companies were imported and exported. ${ }^{5}$

The initiator of the international activities and visits of the Finnish National Theatre and an important agent in the Finnish theatre in general was Arvi Kivimaa. Pirkko Koski has considered Kivimaa to be the most decisive figure in maintaining international links in Finnish cultural history. ${ }^{6}$ As theatre director of the Helsinki Peoples Theatre in the late 1940s, he focused on a Scandinavian and Anglo-American repertoire. He directed, for example, a series of August Strindberg's chamber plays. ${ }^{7}$ Very soon after becoming the director general of the Finnish 
National Theatre in 1950, Arvi Kivimaa started to negotiate for international guest performances. For him, being a theatre internationalist during the Cold War was essential. Modernism, urbanization, internationalism, and national issues emerge repeatedly in Kivimaa's production and work. ${ }^{8}$ In my opinion, international and national issues were not in conflict for Kivimaa; in fact, he combined them in many ways. For example, after WWII it was important for him to develop Finnish theatre and culture towards a more international orientation. Kivimaa can be considered as one of the theatre internationalists who, as Charlotte Canning has defined, saw them [nationalism and internationalism] as integral to their identifications as theatre people. ${ }^{9}$ In 1951, Arvi Kivimaa contacted the director of the Royal Dramatic Theatre, Karl-Ragnar Gierow, about the possibility of guest performances between the two theatres. It is no coincidence that he contacted the Royal Dramatic Theatre in Stockholm first. Among the reasons might have been Kivimaa's personal interest in Scandinavian plays, the cultural connections between the countries, the economic feasibility of the journey, but more importantly, the political neutrality of Sweden, must have surely made the choice easier. However, the negotiations for the visits were long and multiphased. I will refer to them in close order to demonstrate the complicated decision making process and the requirements of cultural diplomacy and geographies of theatre. The multiphase negotiations were needed for achieving both national agreement and international visibility and activity, all of which Kivimaa was looking for for the Finnish National Theatre. First, Kivimaa invited the Royal Dramatic Theatre to perform at the Finnish National Theatre. The visit of the Royal Dramatic Theatre took place in Helsinki in the spring of 1953. The Finnish State encouraged these kinds of visiting performances and the Ministry of Education promised to pay the costs of the visit if the Finnish National Theatre made a loss. ${ }^{10}$ After the visit, the initiator of the guest performance was Karl-Ragnar Gierow. He invited the Finnish National Theatre for a return visit and proposed a Chekhov play as the guest performance. ${ }^{11}$ The board of the Finnish National Theatre acknowledged the invitation to visit with a Chekhov play at the board meeting of September $1953 .{ }^{12}$

The negotiations of the return visit did not progress quickly, although both parties were agreed on the visit as such. The reason for the delay was that they could not agree on the guest performance. Despite Gierow's request to see a Chekhov production in Stockholm, Kivimaa suggested The Rose Tattoo by Tennessee Williams (completed in 1951). According to Kivimaa, the board of the Finnish National Theatre wished to send the theatre to Stockholm with The Rose Tattoo. ${ }^{13}$ According to the board, if the Royal Dramatic Theatre would prefer The Cherry 0 rchard as earlier requested, the second choice would be The Rose Tattoo. Since the board preferred The Rose Tattoo, they sent Arvi Kivimaa to Stockholm to negotiate the details of the visit. ${ }^{14}$

Karl-Ragnar Gierow replied quickly to Kivimaa. It was clear that he did not want to see The Rose Tattoo in Stockholm. Politely, he praised the production of the Finnish National Theatre, but did not consider the play, as such, a very important piece. Besides, in Gierow's opinion, The Rose Tattoo had been performed everywhere in Sweden although not in Stockholm. He suggested a play by Molière, but in the same sentence brought up the possibility of seeing a Chekhov production in Stockholm: according to him, it would be even better than a Molière production. Especially, he mentioned the productions of The Seagull or The Cherry Orchard as most probable successes in Stockholm. ${ }^{15}$ Gierow had seen the production of The Rose Tattoo at the Finnish National Theatre. Arvi Kivimaa was supported by a Swedish theatre critic Ebbe Linde, who wrote an article about Finnish theatre to D agens $N$ yheter, one of the main newspapers in Sweden. According to Linde, The Rose Tattoo was a good production. In his opinion especially the actors Ella Eronen and Holger Salin succeeded in the main roles. Linde suggested that the Finnish National Theatre perform The Rose Tattoo in Stockholm as a guest performance instead of the unavoidable national 
classic, The $\mathrm{H}$ eath Cobblers by Aleksis Kivi. ${ }^{16}$

In Kivimaa's opinion The Rose Tattoo was not a success as a play, but he insisted on the quality of the Finnish National Theatre's production. He, too, considered the interpretations of Chekhov plays by Kalima among the best performances of the theatre. And finally, the main reason for the problem of not being able to decide on the guest performance was explicitly mentioned. According to Kivimaa, the Finnish National Theatre could not consider visiting only with a Russian play. In Kivimaa's opinion, a guest performance of a Chekhov play by the Finnish National Theatre in the political situation of the early 1950s could be interpreted as an act of opportunism. ${ }^{17}$

To avoid the interpretation of an opportunistic act and not visit Stockholm with just a Russian play, Kivimaa suggested a compromise: the Finnish National Theatre could perform a Chekhor play on the main stage of the Royal Dramatic Theatre and another play on the small stage of the Royal Dramatic Theatre. He did not mention which Chekhov production the theatre would choose. $^{18}$ At the time only The Cherry Orchard was in the repertory. ${ }^{19}$ For the second guest performance he suggested a Finnish contemporary play by Walentin Chorell, Matkamies (The Wayfarer) directed by Jack Witikka. It had premiered in 1953 and was received very well. Kivimaa also proposed another possibility, which was a play by Eino Leino, Tarquinius Superbus, which he had just started to rehearse with the actors. Finally, in his reply, he mentioned five other productions the Finnish National Theatre would soon be premiering. ${ }^{20}$ Interestingly, there were no Chekhov productions among them.

Approximately three weeks later, Kivimaa repeated the possibility of giving The Wayfarer as a guest performance in Stockholm but did not mention the possible Chekhov production. ${ }^{21} \mathrm{He}$ even visited Stockholm to discuss the details of the visit at the end of February 1954. Besides Gierow, during his visit, he met the Finnish ambassador in Stockholm G. A. Gripenberg and some members of the Finnish Society in Sweden. According to Kivimaa, they supported the possible visit of the Finnish National Theatre, but advised the theatre to pay special consideration as to the choice of the guest performance. In Kivimaa's opinion, the theatre could probably not use any of the planned productions as the guest performance. It would need a new production, so the board of the Finnish National Theatre decided to postpone the visit to the season 19541955. ${ }^{22}$ It seems clear that the Finnish ambassador in Sweden, Kivimaa, and the members of the board of the theatre did not want the Finnish National Theatre to visit Stockholm with a Chekhov production. Geographies of theatre did indeed matter in choosing the guest production.

Besides the question of choosing the guest performance, another reason for postponing the visit to Sweden was the visit the Finnish National Theatre made to Paris in 1955. It was a return visit too, since Comédie Française had visited the Finnish National Theatre in April 1953. ${ }^{23}$ In Paris, the Finnish National Theatre performed The Miser by Molière directed by Arvi Kivimaa at an international theatre festival. In Kivimaa's opinion, the guest performance in Paris was a beginning in showing Finnish theatre abroad. He was convinced about the importance of the continuation of these visits and according to him, the theatre should visit with a national repertoire in the future. ${ }^{24}$ Furthermore, in the annual report of the season 1951-1952, it was mentioned that the Finnish National Theatre was a pioneer in showing Finnish theatrical life new perspectives. ${ }^{25}$

Regarding the visit to Stockholm, the board of the Finnish National Theatre finally decided to visit Stockholm in the spring of 1956 with a Chekhov production, as requested by the Royal Dramatic Theatre, which was mentioned also in the minutes of the board meeting, and a short scrap of some Finnish play. ${ }^{26}$ The board was very determined to carry out the visit and perhaps a bit worried about whether the visit would happen at all since they agreed on performing a Chekhov play in Stockholm. In the fall of 1955, Kivimaa suggested that the guest performance could be The Three Sisters by Anton Chekhov performed together with a 10-minute extract from some Finnish play before it. In Kivimaa's opinion, The Three Sisters was the best of Kalima's Chekhov 
interpretations and you would get your Chekhov as you always wanted to, he wrote. ${ }^{27}$ This was good news for Gierow and he replied at once. He was very happy about the choice of the guest performance. ${ }^{28}$ The Three Sisters was not in the repertory of the Finnish National Theatre in 1955. Actually, on the very same day Kivimaa wrote to Gierow, he also wrote to Eino Kalima suggesting that he could direct The Three Sisters again. ${ }^{29}$ The production, originally premiered in 1947, returned to the repertory after eight years on 15 February $1956 . .^{30}$ The Finnish National Theatre was supposed to perform the Chekhov production on the main stage and a Finnish play on the small stage of the Royal Dramatic Theatre. ${ }^{31}$ The Chekhov production, performed on the main stage, would have been considered as the main guest performance and the second performance on the small stage less important. However, in the final agreement this was changed: the Finnish National Theatre was scheduled to perform The Three Sisters by Anton Chekhov on the main stage of the Royal Dramatic Theatre on 7 May 1956 and The Seven Brothers by Aleksis Kivi on the same stage of the theatre on 8 May $1956 .{ }^{32}$

Two performances, both on the main stage of the Royal Dramatic Theatre, the long discussed Chekhov production and a Finnish production must have felt like a victory to Arvi Kivimaa and the board of the Finnish National Theatre despite having to compromise on the visiting productions. A visit with The Rose Tattoo and The Wayfarer would have given a different image of the Finnish National Theatre than the visit with The Three Sisters and The Seven Brothers. However, Kivimaa and the board of the Finnish National Theatre did not have to settle for performing only a Chekhov production, which, according to them, could have been interpreted as an opportunist act showing sympathy towards the Soviet Union. The theatre could perform two productions on the same stage.

The decision to perform a Finnish classic adaptation of novel labelled as the national epic, The Seven Brothers by Aleksis Kivi, the national writer, as the Finnish performance was somehow an obvious choice. Already in the late 1930s, the
Finnish National Theatre had visited Stockholm and Tallinn with plays by Aleksis Kivi. The Swedish Theatre in Helsinki had visited abroad with a Kivi play, too. ${ }^{33}$ However, returning to a Kivi play after thinking about The Wayfarer by Walentin Chorell looks like a compromise. The Wayfarer, a modern and poetic play, had been a Finnish attempt to use new theatrical means on stage. For example, the set was designed by architect Heikki Siren mostly using projections, light, and shadow. A much more traditional production, The Seven Brothers, adapted and directed by Wilho Ilmari, was performed at the Finnish National Theatre for the first time on 3 March 1954. It became a steady seller: it had, altogether, 153 performances before it was closed on 22 January $1963 .{ }^{34}$

In my opinion, by suggesting The Rose Tattoo as the guest performance, Arvi Kivimaa wanted to depict the Finnish National Theatre as a theatre, which introduced international, new, and especially Anglo-American plays to Finnish theatre audiences. During the time Kivimaa had run the theatre, he had increased the number of Anglo-American plays in the repertory. In the repertory of the Finnish National Theatre in the 1950s it is easy to see the connections to Western Europe and Scandinavia. Geography and geopolitics did matter in Kivimaa's decisions. Instead of accomplishing his line of repertory also in international guest performances he was asked by Karl-Ragnar Gierow to choose a Russian classic as the guest performance. Thus, it was important for Kivimaa and the Finnish National Theatre to mention on all occasions that The Three Sisters was a request by Gierow. ${ }^{35}$

\section{THE THREE SISTERS IN 1956: WITHIN THE BOUNDS OF POSSIBILITIES}

In the geopolitical situation of Finland in the 1950s, the countries where the plays were written mattered to a nation trying to balance in its ambivalent position. It seems to be that for the Finnish National Theatre it was more acceptable to produce Chekhov's plays for a Finnish audience, but in the 1950s, the theatre did not necessarily want to perform them as guest performances abroad, 
despite director Eino Kalima's (1882-1972) long time interest in Chekhov's plays. Kalima had directed his first Chekhov productions in the mid1910s: Uncle V anya in 1914 and The Cherry O rchard in 1916. Before beginning his work as director general of the Finnish National Theatre, he had studied Slavic languages and had a fellowship to study in Moscow and St. Petersburg in 1904-1908. At the time, Finland was the autonomous Grand Duchy of Finland incorporated into the Russian Empire. In Moscow, Kalima acquainted himself with the Chekhov productions directed by Konstantin Stanislavski at the Moscow Art Theatre. ${ }^{36}$ The early Chekhov productions by Kalima in the 1910s were not considered problematic in terms of the origin of the plays. According to Pirkko Koski, in the reports of the Finnish National Theatre 1914-1916 there are no signs about prejudices against the author or the Russianness of the plays. Besides, Kalima's background as a Slavist was common knowledge. The general reception changed only after 1918, which Kalima himself also recognized. ${ }^{37}$ It seems to have followed more general attitudes: Finnish historian Matti Klinge has argued that after Finland started the process of becoming independent, hostility towards Russia began. ${ }^{38}$ The Russian Revolution in 1917 prompted the Finns to declare the country independent.

Eino Kalima returned to Chekhov plays after a break of thirty years. Before then, he did not want to take the risk of being seen as an unpatriotic person. ${ }^{39}$ The Three Sisters was his third Chekhov production and the premiere on 26 November 1947 was the first time the play was produced in independent Finland. Despite the good reviews, The Three Sisters was not a public success. It received only ten performances and it closed on 10 January 1948. According to Annikki Hyvönen, The Three Sisters gave the opportunity for public acknowledgment although the audience was hesitant towards the origin of the play. ${ }^{40}$ In Pirkko Koski's opinion, the good reviews by recognized theatre critics were an important part in the canonizing process of not only Chekhov plays, but also Kalima's interpretations of them in Finland. ${ }^{41}$ The re-premiere of The Three Sisters in February 1956 received positive reviews in
Finland. It was considered more optimistic than the version Kalima had directed in 1947. ${ }^{42}$

Before the visit, the Swedish audience was given some background information about Finnish theatre and the performances. At the end of April, the newspaper Svensk a D agbladet published an article by Ritva Ahonen about Kalima's long term interest in Chekhov. He was referred to as a Chekhov expert. ${ }^{43}$ Based on Kalima's background as a student of Slavic languages and cultures and his previous work as theatre director with Chekhov's plays this was certainly true. However, there was more to come. In the articles published after the press conference in the Finnish Embassy in Stockholm it was mentioned that the director of The Three Sisters, Eino Kalima, had studied under Konstantin Stanislavski. ${ }^{44}$ Based on the article published in Stockholms Tidningen, it was Arvi Kivimaa who told this to the Swedish press. $^{45}$ In different sources discussing Eino Kalima's fellowship in Russia at the beginning of the 20th century, there is no evidence about his studies with Konstantin Stanislavski, though he saw many productions at the Moscow Art Theatre. ${ }^{46}$ According to Kalima himself, he met Stanislavski only once in 1916. During the meeting they discussed the possibility of Kalima returning to Russia in 1917 in order to study with Stanislavski, but due to the revolution, the plan was never realized. ${ }^{47}$ Still, by labelling Kalima as a student of Stanislavski, Kivimaa created a myth that certainly made it easier to defend the choice of the guest performance. It also increased international interest towards the production of The Three Sisters and Kalima as the director of it.

The Finnish National Theatre prepared a special programme in order to help the Swedish audience in following the guest performances. In the programme, there were four short articles (in Swedish) and lots of advertisements of Finnish products (in Finnish). The first article discussed the history of the Finnish National Theatre, focusing on the main artists of the theatre. The second article was about Finnish Drama, the third about the Finnish National Theatre and Nordic drama. The Finnish National Theatre was told to bond with the Nordic neighbouring countries. 
The theatre's long tradition in performing plays by August Strindberg, Henrik Ibsen and Kaj Munk, but also European classics by William Shakespeare and Molière was mentioned. The last article presented The Seven Brothers by Aleksis Kivi. It is worth noticing that Kivi was mentioned in all four articles also briefly in the article discussing the Finnish National Theatre and Nordic drama. ${ }^{48}$

Anton Chekhov, on the other hand, was mentioned only very briefly in the first article in connection with Eino Kalima's period as the director general of the theatre. According to the article, it was Kalima who introduced the new acting style based on Stanislavski's style and a new repertory consisting mostly of new French plays. He had started the Chekhov-tradition of the theatre. It is interesting to note that it was called the Chekhov-tradition since during his time as the general director of the theatre in 1917-1950 Kalima had only directed two Chekhov productions, The Three Sisters in 1947 and The Seagull in the spring of 1950, which was his last season as the director of the theatre. By 1956, Kalima had directed five Chekhov-productions in all between 1914-1956 and he was the only one who had directed Chekhov plays at the Finnish National Theatre. During the same time, for example, the Finnish National Theatre had performed approximately 30 productions of William Shakespeare's plays. ${ }^{49}$ Besides the pictures of the products advertised in the programme, there were several pictures of the artists of the Finnish National Theatre and five other pictures in the programme. Two pictures were about the stages of the theatre (the interior of the Main Stage and the facade of the Small Stage). Two pictures presented the productions of the theatre, the main actors of To Damascus by August Strindberg and a picture showing the set of The Wayfarer by Walentin Chorell. The fifth picture was about the statue of Aleksis Kivi by sculptor Wäinö Aaltonen. ${ }^{50}$

\section{THE TWO PRODUCTIONS IN STOCKHOLM}

The Swedish press covered the guest performances very well. Not only the local newspapers in Stockholm, but also other newspapers in other parts of the country published articles and reviews. The Swedish reviews paid attention to the whole ensemble and to the evenness of the quality of the ensemble of the Finnish National Theatre in both guest performances. According to the reviews, The Three Sisters was considered the main guest performance and The Seven Brothers accompanied it. However, the Queen of Sweden attended only the latter performance. It is interesting to note that the first time the Finnish National Theatre's interpretation of The Thre Sisters was performed outside of Finland, Lennart Josephson wrote to the Sydsvenska Dagbladet that the production was internationally famous. ${ }^{51}$

Based on the reviews in general, The Three Sisters, was considered a successful production with high artistic quality. Many critics mentioned that they, as well as the majority of the audience, did not understand the Finnish spoken on the stage. Naturally, the critics knew the play in advance and according to them, it was possible to understand the deep emotions and the refined atmosphere of the performance without understanding the dialogue. ${ }^{52}$ The director, Eino Kalima, received most of the attention in the reviews. He was credited for his expertise in interpreting Chekhov's plays. Many critics mentioned this was due to his background as Stanislavski's student. Kalima was appreciated in achieving the real Russian tone that met all the expectations. ${ }^{53}$ One critic of the 1947 production emphasized exactly the same thing: according to Huugo Jalkanen, for the Finnish ensemble it could not have been possible to perform the Slavic tone of life any better. ${ }^{54}$

In my opinion, the Swedish critics mainly strengthened the myth the Finnish National Theatre had created. They repeated the information they had received at the press conference and in the articles published before the guest performances. For example, the critic of newspaper A ftonbladet wrote: he [Kalima] has learned all there is to learn from Stanislavski and the other Russians. ${ }^{55}$ In A. Gunnar Bergman's opinion, the Stanislavski influence was very visible in the production. He had never seen any director come so close to Stanislavski's ideal interpretation. 
He also wrote: director Eino Kalima, scenography designer Karl Fager and the whole ensemble proved that Finland is an ocean closer to Russia than Sweden. Probably, they are an ocean closer to the old Russia, Chekhov's Russia. It is interesting how the good quality of the Chekhov production was, at least partly, explained with geography. Yet, the title of Bergman's review was No-one can be more Finnish. ${ }^{56}$

According to the Swedish critics, the guest performances gave an impression of the width of the repertory of the Finnish National Theatre. ${ }^{57}$ Not all the spectators could understand Finnish and, unlike The Three Sisters, they did not know The Seven Brothers in advance. In order to assist the audience, actor Matti Ranin gave short summaries in Swedish as a narrator. In one critics opinion, he looked like Aleksis Kivi in Wäinö Aaltonen's statue. ${ }^{58}$ The Seven Brothers was mainly appreciated because it differed from the Chekhov production. For some critics it was too rustic, for some not rustic enough. Per Erik Wahlund wrote in Svenska D agbladet: More Finnish Finns from Finland one could not imagine than the seven illiterate brothers with linen blond hair, faces made of stone [...] nothing would be safer than to have such guys as lifeguards. ${ }^{59}$ In A. Gunnar Bergman's opinion, the director of the production, Wilho Ilmari, and the actors performed two different interpretations. According to him, the directors interpretation was too clean compared to the robust and true-Finnish characters. The reviewer used the term Hollywood clean. ${ }^{60}$

Gunnar Falk wrote a review after the guest performances for the newspaper $\mathrm{G}$ efle $\mathrm{D}$ agblad. $\mathrm{He}$ discussed in his article how theatre participates in the production of national images in performing both domestic and foreign plays. In his opinion, acting in the theatre was very similar in Finland compared to Sweden. However, emotions were more visible in Finnish acting. He paid attention to the long pauses in the performance of The Three Sisters. He referred to the fine Chekhovtradition of the Finnish National Theatre. His explanation of it was that Chekhov's milieu and mentality was very well understood in Finland. ${ }^{61}$ Interestingly, several critics mentioned how successfully the Finnish ensemble created the Russian atmosphere of The Three Sisters, but not many of them paid attention to the quality of the ensemble in producing a Finnish atmosphere in The Seven Brothers. They seem to have taken it for granted. Perhaps from the viewpoint of the Swedish critics, geographies of Finland and Finnish theatre were intertwined: being Finnish included the cultural ability to understand and perform the Russian tone extremely well. Geographically, in Europe, Finland was undeniably an eastern country.

\section{CONCLUSIONS}

In this article I have discussed the Finnish National Theatre's visit to Stockholm in May 1956 by looking at geographies of theatre, international theatre visits and cultural diplomacy. It was important for the director general, Arvi Kivimaa, and the board of the Finnish National Theatre to pay attention to the initial nationality of the play: though the question of nationality when discussing theatre performances is a complicated one. It seems to be that political alliances affected cultural diplomacy profoundly. The Finnish National Theatre produced background material for the Swedish audience and organized a press conference at the Finnish Embassy in Stockholm. The Finnish National Theatre turned the disconcerting question of the origin of The Three Sisters to their advantage. Labelling Eino Kalima as a student of Stanislavski connected the production to the time Kalima studied in Russia at the beginning of the century. ${ }^{62}$ Connecting the production to Russia made it easier to perform it in a historical moment when the relationship between Finland and the Soviet Union was complicated. In addition to this, Kalima's expertise in interpreting Russian classics gave a good reason for choosing the guest performance. The created myth was useful not only internationally but on the home front as well. In the reception of the visiting performances, the myth was connected to the geographies of theatre. Not only the myth about Kalima but also the Finnish National Theatre's geographies, the theatre's cultural, political, and historical context seemed to explain the good quality of the Chekhov 
production.The reception of the Stockholm visit was very useful for the Finnish National Theatre. Besides the good reviews in Helsinki and in Stockholm, The Three Sisters also attracted an audience in Helsinki: it was performed 56 times before the last performance on 29 May $1960 .{ }^{63}$ This period included two performances for an international audience during the ITI world congress held in Helsinki in June 1959. ${ }^{64}$ Encouraged by the good reviews the production received in Stockholm, the Finnish National Theatre planned to perform it in Paris, Copenhagen, and Vienna in 1957 and it was also offered to the Edinburgh Theatre Festival. ${ }^{65}$ In his letter to the Edinburgh Festival Office, Jack Witikka, director at the Finnish National Theatre sustained and strengthened the myth. The international press he referred to consisted mainly, or perhaps only, of Swedish newspapers: It has been said that the best and truest Chekhov today is to be seen at the Finnish National Theatre. This may sound pompous were it not for the fact that this statement has been made by an international press as well as public. The fact that our former director general, professor Eino Kalima, worked with Stanislavski and has upheld his tradition in its finest sense, should bear this out. Next Spring, our theatre will perform Chekhov's Three Sisters in Paris, Vienna and Copenhagen, following this years highly successful visit to Sweden. ${ }^{66}$

Despite the good reviews, The Three Sisters received both in Helsinki and in Stockholm, the Stockholm visit was the only time the production visited abroad. In 1957, the Finnish National Theatre visited Copenhagen and Vienna performing The Seven Brothers by Kivi and Iphigenia at A ulis by Euripides. The reason for replacing The
Thre Sisters with Iphigenia at A ulis might have been the fact that Kivimaa himself had directed the Euripides' play. However, the Finnish National Theatre returned to Chekhov when they chose the next guest performance. The myth enabled the Finnish National Theatre to do so. It drew international interest towards the interpretation by Kalima and the Finnish National Theatre even though it strengthened the image of Finland as an eastern country. In 1961, the Finnish National Theatre visited West Berlin with The Seagull directed by Kalima. The Parisian audience saw The Seagull in 1962. In West Berlin and Paris, the Finnish National Theatre visited with one production, but in 1962, during the visits to Moscow and St. Petersburg, The Seagull was performed together with The Seven Brothers. ${ }^{67}$ In Lübeck in 1963, the theatre performed The Seagull together with Samuel Beckett's Krapps L ast Tape. ${ }^{68}$ I need to look at the details of these visits more closely, but one significant difference is the time of the event. Politically, the beginning of the 1960s was a more stable time in Finland than the 1950s, even though the country could not be aligned and it was still balancing between the East and the West. With all the visits the Finnish National Theatre undertook after World War II, the agenda of the theatre was to strengthen the nations cultural connections to the Western bloc. It is obvious that the success of The Three Sisters in Stockholm in 1956 and the usefulness of the myth about Kalima as Stanislavski's student increased international interest towards the Finnish National Theatre and was the ticket, which enabled Finnish theatre to travel across the borders of Europe. 


\section{NOTES AND REFERENCES}

1. Joanne Tompkins, "Space and the Geographies of Theatre: Introduction," M odern D rama vol. 46:4. 2003, pp. 537-541.

2. Jukka Nevakivi, "From the continuation war to the present, 1944-1999," From G rand D uchy to a Modern State. A Political H istory of Finland sinc 1809, Osmo Jussila, Seppo Hentilä, Jukka Nevakivi, eds., Hurst \& Company, London 1999, pp. 282-284.

3. Johanna Rainio-Niemi, The Ideological C old W ar. The Politics of N eutrality in A ustria and Finland, Routledge Taylor \& Francis Group. New York 2014, p. 5.

4. In fact, the ITI was one of the very first international organizations Finland could join in the post war political climate.

5. Charlotte M. Canning $0 \mathrm{n}$ the Performanœ Front U S Theatre and Internationalism, Palgrave Macmillan, Basingstoke 2015, p. 23.

6. Pirkko Koski, "Arvi Kivimaa," N ational Biography of Finland. Finnish Literature Society. http://www.kansallisbiografia.fi. accessed 4.9.2015.

7. Ibid.

8. Hanna Korsberg, "Open the Windows on Europe! Arvi Kivimaa's Work and Literary Production in the 1920s and Early 1930s." Comparative approaches to E uropean and $\mathrm{N}$ ordic M odernisms. Mats Jansson, Janna Kantola, Jakob Lothe and H. K. Riikonen, eds., Palmenia, Helsinki 2008, pp. 59-78.

9. Canning, op.cit., p. 22.

10. A letter from Arvi Kivimaa to Karl-Ragnar Gierow 14.11.1951. E I h:1. In the archive of the Royal Dramatic Theatre; The minutes of the board meeting of the board meeting of the Finnish National Theatre 5.5.1953.

11. A letter from Karl-Ragnar Gierow to Arvi Kivimaa 16.9.1953. E I h:5. The archive of the Royal Dramatic Theatre.

12 The minutes of a board meeting of the Finnish National Theatre 22.9.1953. The archive of the Finnish National Theatre.

13. A letter from Arvi Kivimaa to Karl-Ragnar Gierow 16.1.1954. E I h:5. The archive of the Royal Dramatic Theatre.

14. In the minutes of the meeting of the board of the Finnish National Theatre 15.1.1954, the board suggested The Rose Tattoo. According to the minutes of the meeting, the Chekhov production that was discussed earlier was The C herry 0 rchard. The minutes of the board meeting of the Finnish National theatre 15.1.1954. The archive of the Finnish National Theatre.

15. A letter from Karl-Ragnar Gierow to Arvi Kivimaa 21.1.1954. E I h:5. The archive of the Royal Dramatic Theatre. Original letter in Arrived letters 1954-1955. The archive of the Finnish National Theatre.

16. Ebbe Linde, "Teatersvep i österled", D agens $N$ yheter 30.12.1953.

17. A letter from Arvi Kivimaa to Karl-Ragnar Gierow 27.1.1954. E I h:6. The archive of the Royal Dramatic Theatre.

18. A letter from Arvi Kivimaa to Karl-Ragnar Gierow 27.1.1954. E I h:6. The archive of the Royal Dramatic Theatre.

19. The Record II of the Finnish National Theatre. The archive of the Finnish National Theatre.

20. A letter from Arvi Kivimaa to Karl-Ragnar Gierow 27.1.1954. E I h:6. The archive of the Royal Dramatic Theatre.

21. A letter from Arvi Kivimaa to Karl-Ragnar Gierow 16.2.1954. E I h:6. The archive of the Royal Dramatic Theatre.

22. The minutes of the board meeting of the Finnish National Theatre 25.2.1954. The archives of the Finnish National Theatre; A letter from Arvi Kivimaa to Karl-Ragnar Gierow 28.2.1954. E I h:6. The archive of the Royal Dramatic Theatre.

23. The minutes of a board meeting of the Finnish National Theatre 23.1.1953. The archive of the Finnish National Theatre.

24. Arvi Kivimaa, Teatterin humanismi. Avajaispuheita 1950-1971, Otava, Helsinki 1972, p. 58.

25. It is very likely Kivimaa had written the annual report himself. The annual report of the season 1951-1952, p.

2. The archive of the Finnish National Theatre.

26. The minutes of the meeting of the board of the Finnish National Theatre 31.5.1955. The archive of the Finnish National Theatre.

27. A letter from Arvi Kivimaa to Karl-Ragnar Gierow 15.8.1955. E I h:8. The archive of the Royal Dramatic Theatre.

28. A letter from Karl-Ragnar Gierow to Arvi Kivimaa 18.8.1955. E I h:10. The archive of the Royal Dramatic Theatre.

29. A letter from Arvi Kivimaa to Eino Kalima 15.8.1955. 
The archive of the Finnish Literary Society.

30. By performing The Three Sisters on 29 January 1960, the Finnish National Theatre celebrated the centennial of Anton Chekhov's birth. The Record II. The archive of the Finnish National Theatre.

31. A letter from Arvi Kivimaa to Karl-Ragnar Gierow 17.1.1956 and a letter from Karl-Ragnar Gierow to Arvi Kivimaa 24.2.1956. E I h:10. The archive of the Royal Dramatic Theatre.

32. The contract between the Royal Dramatic Theatre and the Finnish National Theatre 22.2.1956. An enclosure to the minutes of the board meeting of the Royal Dramatic Theatre 22.2.1956. The archive of the Royal Dramatic Theatre.

33. In April 1936, there had been A Finnish week in Stockholm and during that, the Finnish National Theatre had performed two performances. First, three chamber plays by Aleksis Kivi, Kihlaus, L ea and Y ö ja päivä and then, Tartuffe by Molière at the Royal Dramatic Theatre. The Swedish Theatre in Helsinki had performed D en stora världsteater six times and Aleksis Kivis Sodkensk omakarna four times in September 1935. Styrelseberättelse och revisionsberättelse 1935-1936. The Archive of the Royal Dramatic Theatre.

34. Besides Stockholm, the Finnish National Theatre performed The Seven Brothers in Copenhagen and Vienna in 1957 and in Moscow and in St. Petersburg in 1962. The Record II. The archive of the Finnish National Theatre.

35. For example, the minutes of the board meeting of the Finnish National Theatre 31.5.1955 and the letter from Arvi Kivimaa to the Ministry of Education 30.9.1955. Sent letters 1955-1956.The archives of the Finnish National Theatre.

36. Kari Ketola, Ryssän koulussa. Suomalaiset V enäjän stipendiaatit autonomian aikana 1812-1917. Finemor Oy, 2007, p. 137.

37. Pirkko Koski, "Tšehovin näytelmien kanonisointi Suomessa. Eino Kaliman ohjaukset tradition murroksessa" N iin muuttuu mailma, E skoni. Tulkintoja Kansallisnäyttämöstä, Pirkko Koski, ed., Yliopistopaino, Helsinki 1999, p. 159.

38. Matti Klinge, V ihan veljistä valtiososialismiin. WSOY, Helsinki, 1972, p. 70.

39. Annikki Hyvönen, E ino Kalima T šhov-ohjaajana. Suomalaisen Kirjallisuuden Seura, Helsinki, 1986 p. 96.
40. Ibid., p. 97.

41. Koski, op.cit., p. 167.

42. Hyvönen op. cit., p. 108.

43. Ritva Ahonen, "Finsk Tjechovexpert svarar för Tre Systrar på The Royal Dramatic Theatre," Svenska D agbladet, 29.4.1956.

44. "Sju bröders landskap pussel på The Royal Dramatic Theatre," Svenska D agbladet 6.5.1956; "Finskt gästspel med 10 syskon," Stock holms Tidningen, 6.5.1956.

45. Ly: "Finskt gästspel med 10 syskon," Stodk holms Tidningen 6.5.1956.

46. Koski, 2015, op cit., accessed 10.9.2015; Koski, 1999, op cit.; Hyvönen, op.cit.

47. Eino Kalima, Sattumaa ja johdatusta, WSOY, Helsinki 1962, pp. 320-322.

48. "Svårt göra slut med Kivi," D agens N yheter, 6.5.1956.

49. ILONA a Finnish theatre database of performances, http://ilona.tinfo.fi/ (home page), accessed 10.1.2016.

50. The program of the guest performances of the Finnish National Theatre. The archive of the Royal Dramatic Theatre.

51. Lennart Josephson, "Det finska gästspelet," Sydsvenska D agbladet, 11.5.1956.

52. Martin Strömberg, "Tjechov i lysande gästspel," Stodk holms Tidningen 8.5.1956; Ebbe Linde, "Den finska Tre systrar," D agens N yheter 8.5.1956; Nils Beyer, "Finska gästspelet," M orgon-Tidning 8.5.1956; Per Erik Wahlund, "Eino Kalima och Tre systrar," Svenska D agbladet 8.5.1956. One critic, Viveka Heyman in D agens Tidningen, wrote how difficult the performance was for all those who did not understand Finnish. Viveka Heyman, "Festligt finskt på The Royal Dramatic Theatre," D agens Tidningen 9.5.1956.

53. Ebbe Linde, "Den finska Tre systrar," D agens N yheter 8.5.1956.

54. Huugo Jalkanen, U usi Suomi 28.11.1947.

55. S. S-s, "Ryskt på finskt vis," A ftonbladet 8.5.1956.

56. A. Gunnar Bergman, "Finskare kan ingen vara," A ftontidningen 8.5.1956.

57. Martin Strömberg, "Tjechov i lysande gästspel," Stock holms Tidningen 8.5.1956; Nils Beyer, "Finska teaterns andra kväll," M orgon-Tidningen 9.5.1956.

58. Tord Bæckström, "Finskt gästspel på The Royal Dramatic Theatre," G öteborgs handels- och sjöfartstidning 11.5.1956.

59. Per Erik Wahlund, "Kivi på finska," Svensk a D agbladet 9.5.1956. 
60. A. Gunnar Bergman, "Sju prydliga små pojkar," A ftontidningen 10.5.1956.

61. Gunnar Falk, "Teatern förkunnar," G efle D agbladet 14.5.1956.

62.http://yle.fi/elavaarkisto/artikkelit/kansallisteatterin_lok ki_liiti_maineeseen_79411.html\#media=14177.

63. The Record II of the Finnish National Theatre. The archive of the Finnish National Theatre.

64. Hyvönen op.cit., 109.

65. A letter from Jack Witikka to the Edinburgh Festival Office 28.9.1956. The received letters 1955-1956. The Finnish National Theatre; A letter from Nils Lund to Arvi Kivimaa 3.12.1956. The received letters 1955-
1956. The archive of the Finnish National Theatre.

66. A letter from Jack Witikka to the Edinburgh Festival Office 28.9.1956. The correspondence 1955-1956. The Archive of the Finnish National Theatre.

67. Katri Mehto, "Ifigeneia ja Seitsemän veljestä maailmalla. Kansallisteatterin vuoden 1957 vierailut kansallista identiteettiä vahvistamassa," $\mathrm{N}$ iin muuttuu mailma, E sk oni, Pirkko Koski, ed., Yliopistopaino, Helsinki, 1999, p. 252.

68. The Finnish National Theatre in Lübeck 18 and 19 May 1963. The program of the visit published by Deutsche Auslandsgesellschaft. The Archive of the Finnish National Theatre.

Since 2008, Hanna Korsberg has been Professor of Theatre Research at the University of Helsinki. Her research interests include the relationship between theatre and politics in Finland, a topic which she has studied in two monographies. She is also the author of several articles discussing theatre history, historiography and performance analysis. She has been an active member of the IFTR Historiography Working Group since 2001, an executive committee member (2007-2015), and a vice president (2015-2019). She has served as a member of the advisory boards for Contemporary Theatre Review and Nordic Theatre Studies. She is also a member of the Teachers' Academy at the University of Helsinki. 